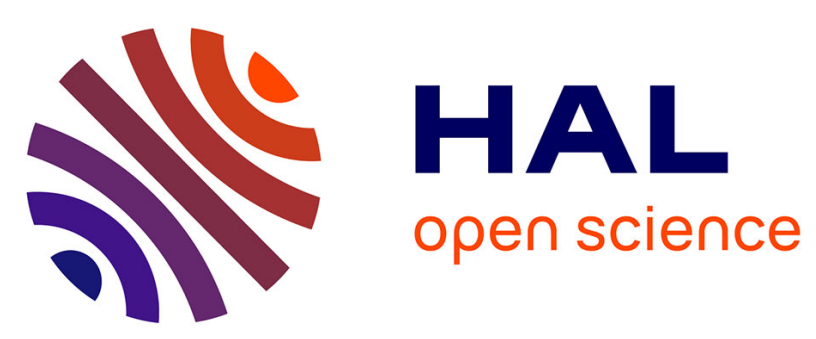

\title{
Ethnic gaps in educational attainment and labor-market outcomes: evidence from France
}

\author{
Gabin Langevin, David Masclet, Fabien Moizeau, Emmanuel Péterlé
}

\section{To cite this version:}

Gabin Langevin, David Masclet, Fabien Moizeau, Emmanuel Péterlé. Ethnic gaps in educational attainment and labor-market outcomes: evidence from France. Education Economics, Taylor \& Francis (Routledge), 2016. halshs-01878878v2

\section{HAL Id: halshs-01878878 \\ https://halshs.archives-ouvertes.fr/halshs-01878878v2}

Submitted on 6 May 2021

HAL is a multi-disciplinary open access archive for the deposit and dissemination of scientific research documents, whether they are published or not. The documents may come from teaching and research institutions in France or abroad, or from public or private research centers.
L'archive ouverte pluridisciplinaire HAL, est destinée au dépôt et à la diffusion de documents scientifiques de niveau recherche, publiés ou non, émanant des établissements d'enseignement et de recherche français ou étrangers, des laboratoires publics ou privés. 


\title{
Ethnic Gaps in Educational Attainment and Labor-Market Outcomes: Evidence from France
}

\author{
Gabin Langevin ${ }^{\ddagger}$, David Masclet*,Fabien Moizeau ${ }^{\#}$, Emmanuel Peterle $^{ \pm}$
}

\section{April 2016}

\begin{abstract}
We use data from the Trajectoires et Origines survey to analyze ethnic gaps in education and labor-market outcomes between second-generation immigrants and their French native counterparts. Our three main findings underscore the importance of family background in explaining lifelong ethnic inequalities. First, second-generation immigrants are on average less likely to experience education success than their native counterparts, with the education gap mainly being rooted in ethnic differences in family backgrounds. Second, while second-generation immigrants have on average a lower probability of employment and lower wages than natives, both gaps are mainly explained by the differences in education. Third, we find considerable heterogeneity across ethnic groups.
\end{abstract}

Keywords: labor-market discrimination, second-generation immigrants, educational attainment, family background, decomposition methods.

JEL classification codes: I2, J15, J24, J41. 
Acknowledgments: The authors are very grateful to Caroline Berchet and FrançoisCharles Wolff for their comments on an earlier version of this paper. The authors also thank seminar participants at GAINS (Université du Maine) as well as conference participants at the 2013 Journées de Microéconomie Appliquée (Nice) and the 2013 CREM-INRA Workshop (Rennes). Financial support from the Agence Nationale de la Recherche (ANR-12-INEG-0002) is gratefully acknowledged.

¥Dares, 39-43 quai André Citroën, 75015 Paris, France.

Tel.: +3322323 35 58. E-mail: gabin.langevin@travail.gouv.fr.

* CREM (CNRS - Université de Rennes 1) and CIRANO, 7, place Hoche, 35065 Rennes, France.

Tel.: +33 2232333 18. E-mail: david.masclet@univ-rennes1.fr.

\# CREM (CNRS - Université de Rennes 1) and Institut Universitaire de France,

7, place Hoche, 35065 Rennes, France. Tel.: +33 2232335 87. E-mail: fabien.moizeau@univ-rennes1.fr.

${ }^{ \pm}$CRESE EA3190, Université de Bourgogne Franche-Comté,

30 avenue de l'Observatoire, 25030 Besançon, France. Tel.: +33 3816667 52. E-mail :

emmanuel.peterle@univ-fcomte.fr. 


\section{Introduction}

In recent years, a number of European countries have experienced unprecedented flows of immigrants, mostly from Africa and the Middle East. These recent immigration flows raise important questions about the economic assimilation of immigrants. To what extent are OECD countries able to absorb these flows of immigrants? And do differences in market outcomes depend on where the immigrants came from?

An extensive literature has attempted to provide some answers to these questions by examining the differences between natives and immigrants in terms of employment (see, among others, Bevelander and Nielsen, 2001, for Sweden; Blau and Kahn, 2005, for the US; and Meurs and Pailhé, 2010, and Aeberhardt et al. 2010a, b, for France), earnings (see, among others, Chiswick 1978, Borjas, 1995, and Altonji and Blank, 1999, for the US; Constant and Massey 2003, for Germany; Longva and Raaum, 2003, for Norway, and Aeberhardt and Pouget, 2010, and Aeberhardt et al. 2010a,b, for France) and educational attainment (see, among others, Card, DiNardo and Estes, 2000, for the US; Gang and Zimmermann, 2000, and Casey and Dustmann, 2008, for German; Van Ours and Veenman, 2003, for the Netherlands; Algan et al., 2010, for French, German and British evidence; Dustmann and Glitz, 2011, for evidence from OECD countries).

Most of this work finds that immigrants are $i$ ) less likely to be employed, $i$ ) earn on average significantly less than do natives and iii) perform worse at school than natives. However the existing literature also stresses that these ethnic gaps fall over time. For instance, some work reveals that second-generation children perform better academically than the firstgeneration counterparts, and as well or even better than natives (Rong and Grant, 1992; Kao and Tienda, 1995; Chiswick and DebBurman, 2004; Algan et al. 2010; Dustmann et al, 2010; 
and Dustmann, 2012). ${ }^{1}$ Empirical evidence also indicates that the younger the age at arrival the better are language fluency and educational attainment (see, for instance, Bleakly and Chin, 2010; Domingues Dos Santos and Wolff, 2011). ${ }^{2}$ There is also strong support for the differences in parental educational attainment between natives and immigrants being to an extent reproduced in the next generation (see, among others, Chiswick, 1977, Borjas, 1993, and Card et al. 2008, for the US; Gang and Zimmerman, 2000, for Germany; Van Ours and Veenman, 2001, for the Netherlands; and Domingues Dos Santos and Wolff, 2011, for France). It has also been shown that the socio-economic integration of immigrants differs by ethnic group. For instance, in France, immigrants from the Maghreb suffer from greater unemployment than do other ethnic groups (e.g. Meurs et al., 2006; Meurs and Pailhé, 2010). Other work finds that Muslim immigrants integrate less and more slowly than do non-Muslims, suggesting that Muslim immigrants face greater difficulties in adapting within their host countries than other immigrant groups (see Bisin et al. 2008 for the UK and Constant et al. 2006 for Germany). Regarding educational attainment, some US research shows that Asians outperform other groups, while Hispanic students do less well compared to Asians and non-Hispanic Whites (Hirschman and Wong, 1986; Arias, 1986; Lee and Rong, 1988). Using data on immigrants living in France, Mitrut and Wolff (2014) find no difference in the education of children of Muslim and non-Muslim immigrants, but observe more within-family inequality in children's educational achievements among Muslims relative to non-Muslims.

\footnotetext{
${ }^{1}$ For instance, Dustmann et al (2010) find that while minority groups start off with lower achievement outcomes at school entry, they tend to outperform white British children by age 16.

${ }^{2}$ Using the British school census, Dustmann et al. (2010) compare the educational outcomes of children from ethnic minority groups and native children from the ages of 5 up to 16. Improved English language proficiency is the most important factor explaining why ethnic minorities improve relative to their British counterparts. Furthermore, language proficiency also affects social integration (see Bleakly and Chin, 2010).
} 
We here contribute to this existing literature by examining both educational and labormarket inequalities between natives and second-generation immigrants in France. Our contribution to the existing literature is threefold.

First, we investigate ethnic gaps over the life cycle. This contrasts with previous work that focussed either on labor-market outcomes or educational attainment in isolation. We begin by examining the determinants of educational attainment and the ethnic education gap, underlining the central role of family background (e.g. parental education, family income and family structure) as the key determinants of education. We then examine the determinants of employment and wages, shedding light on the employment and wage gaps between French natives and second-generation immigrants, ${ }^{3}$ emphasizing the effect of particular ethnic group membership. Taking this sequential approach, we assess the effects of ethnic groups through three main channels: educational attainment, employment and wages. Possible endogeneity and selection issues do however need to be addressed here. There may be a potential selection bias in the estimation of wages due to wages only being observed for those in work. We control for this selection bias using a Heckman two-step procedure. In addition, estimates of employment and wages may suffer from endogeneity bias as the explanatory education variable may be correlated with the error term. While previous work has attempted to control either for the selection bias or the endogeneity bias, we here account for both by estimating a bivariate probit model that consists of two simultaneous equations, one for the binary outcome "failure in education" and another for "being employed" followed by the Mincer equation.

\footnotetext{
${ }^{3}$ Note that, for convenience, we consider as natives only those respondents whose parents were both born with French nationality, although from a legal point of view, immigrants' descendants born in France are also French natives as a result of the French jus solis.
} 
Second, we investigate the heterogeneity across different ethnic minority groups of second-generation immigrants in France. This contrasts with most previous work that has concentrated mostly on one ethnic group only. According to Chiswick (1988), there are at least three main factors to explain why ethnic groups may differ in their level of educational attainment. A first reason is that some ethnic groups may be over-represented among lowerclass individuals (Dos Santos and Wolff, 2011). This is consistent with Becker (1972) and Becker and Tomes (1986), who show that an intergenerational correlation in education may result from better-off parents being more likely to invest in the education of their children, ceteris paribus. Immigrants from some ethnic groups with poor social backgrounds may then provide less human and financial capital for the education of their children. Second, some communities may have a greater "taste" for schooling than others due to cultural, religious differences, which may lead some ethnic groups to invest more in the schooling of their descendants (Chiswick, 1988, Dos Santos and Wolff, 2011, and Fryer and Torelli, 2010, for an empirical analysis of ethnic identities and 'Acting White'). Third, members of some communities may be (un)consciously discriminated against with regard to access to schooling and their choice of educational track (Losen and Orfield, 2002; Dos Santos and Wolff, 2011). For instance teachers may have lower expectations regarding non-native students (Fryer and Levitt, 2004). Furthermore some communities may anticipate that the return to their investment in education will be lower due to discrimination, which may incite them to invest less in human capital (Altonji and Blank, 1999). ${ }^{4}$

Our last contribution is the use of an original data set from the French Trajectoires et Origines (TeO) survey that provides rich information on the family and social background of second-generation immigrants in France to investigate differences in educational and labor-

\footnotetext{
${ }^{4}$ Note that our data do not allow us to isolate the effect of each of these motives.
} 
market outcomes between native and other ethnic groups. This data set has only rarely been used in other French work on ethnic gaps in both education and labor-market outcomes between second-generation immigrants. There are a number of reasons to focus on French immigration. First, France is traditionally considered as a country of immigration. For instance, France was the country with the largest share of migrants in 1920 after the US, and since the middle of the 1970 s the share of immigrants in the population has remained relatively stable with about $25 \%$ of the population having some immigration background from the first, second, and third generation by the early 2000s (Algan et al., 2012; Aeberhardt et al., 2010). Another important feature of French immigration is its diversity, with the ethnic composition of migrants becoming increasingly diverse over recent decades (e.g. Algan et al., 2012). French immigration is also mostly characterized by low-skilled immigrants, which differs from other countries such as Canada, the United Kingdom or Australia (Dustmann and Glitz, 2011). For instance, the living standards of individuals with immigrant parents in France are on average 14\% lower than those of natives; this may be potentially a source of tension, as shown by the French riots that occurred in 2005 in many poor suburbs of large cities where immigrants were over-represented (e.g. Lombardo and Pujol, 2011; Aeberhardt et al., 2010). ${ }^{5}$

Despite these numerous reasons to investigate French immigration, the empirical analysis of the ethnic gaps in both educational attainment and labor-market outcomes in France is surprisingly sparse. This contrasts sharply with the vast literature on racial discrimination and the social integration of immigrants in a number of other countries (see Altonji and Blank, 1999, and Borjas, 1999, for surveys). One likely explanation is that, up until recently, information regarding ethnicity was not collected in French survey data. The French egalitarian ideal, which

\footnotetext{
${ }^{5}$ In November 2005, a wave of violence swept through the suburbs of a number of French cities. Faced with this sudden rise in tension, some commentators underlined long-standing integration problems, including discrimination against minorities and the lack of job opportunities in the suburbs that are mainly populated by immigrants.
} 
rejects any form of categorization into ethnic groups, is often evoked to explain this lack of ethnic information and the reluctance of public authorities to provide information on ethnicity. A few notable exceptions are the recent contributions of Laine and Okba (2005), Meurs et al. (2006), Dustmann et al. (2008), Aeberhardt and Pouget (2010), Aeberhardt et al. (2010a, b), Belzil and Poinas (2010), Algan et al. (2010), Domingues Dos Santos and Wolff (2011), Brinbaum et al. (2012) and Akgüç and Ferrer (2015). This work has shown that the educational attainment and labor-market outcomes of immigrant groups are generally worse than those of natives.

Brinbaum et al. (2012) also use $\mathrm{TeO}$ data to look at the differences in education between natives, second-generation immigrants, and immigrants whose education in France began at the primary-school level. Our approach differs from theirs as we focus on lifelong ethnic inequalities and ask how educational differences translate into employment and wage gaps. In a recent paper, Akgüç and Ferrer (2015) also investigate ethnic gaps in labor-market outcomes using the $\mathrm{TeO}$ dataset, ${ }^{6}$ and find that first-generation immigrants are less educated than natives and that there is a significant wage gap. However, we here focus our attention on the comparison between second-generation immigrants and natives, which allows us to compare individuals who have all gone through the French education system.

Our analysis is also related to the seminal papers of Aeberhardt and Pouget (2010) and Aeberhardt et al. (2010a). Aeberhardt and Pouget (2010) analyze national-origin wage differentials in France, and find that these mostly reflect differences in the type of jobs individuals take up, according to their experience, background and education. ${ }^{7}$ Using data from the "Formation Qualification Professionnelle" survey, Aeberhardt et al. (2010a) investigate the wage and employment gaps between French natives and French workers with at least one

\footnotetext{
${ }^{6}$ We only became aware of this contribution after starting to write our paper.

${ }^{7}$ A similar empirical analysis of "Emploi en Continu" data confirms these findings (see Aeberhardt et al., 2010b).
} 
African parent. They conclude that the unexplained portion of the employment decomposition is much larger than that of the wage decomposition. Labor-market discrimination in France is found to be more frequent at the hiring stage than in earnings. Our paper is also related to that of Belzil and Poinas (2010), who estimate a dynamic model of schooling choices and early access to permanent employment contracts in France. Using data from the "Generation 98" survey, Belzil and Poinas (2010) investigate the differences between second-generation immigrants and their French-native counterparts in terms of access to permanent employment contracts. Education is found to be the main determinant of permanent-employment differentials. After controlling for education and other observed characteristics, ethnic origin explains less than $6 \%$ of this employment gap. However, in contrast to Belzil and Poinas (2010) who only consider permanent employment contracts in the early career, we here also focus on the determinants of wages.

This existing work has controlled either for the endogeneity of education or for sample selection (Sloane et al. 1999; Aeberhardt et al., 2010a, b; and Akgüç and Ferrer, 2015). We are different as we investigate the ethnic gaps over the life cycle and attempt to account for both selection and endogeneity biases. We also investigate differences across various subpopulations of second-generation immigrants (North African, Sub-Saharan African, Turkish, Asian, Eastern European, Northern European and Southern European), while most of the above work has concentrated on one ethnic group only. For instance Aeberhardt et al. (2010) consider second-generation African immigrants compared to French natives.

We will below show that: $i$ ) second-generation immigrants are on average less likely to experience education success than their French native counterparts, and that this education gap seems to be mainly rooted in ethnic differences in family backgrounds; $i$ ) second-generation immigrants are on average less likely to be employed and receive lower wages than French natives; iii) a large part of the labor-market differences between French natives and second- 
generation immigrants can be attributed to differences in education; and $i v$ ) there is considerable heterogeneity between ethnic groups both in terms of educational attainment and labor-market outcomes, which is also mainly driven by differences in social and familial background.

The remainder of the paper is organized as follows. Section 2 presents the TeO survey and our sub-sample analysis, and Section 3 then presents our main findings. Last, Section 4 discusses and concludes.

\section{The dataset and methodology}

\subsection{Presentation of the data set}

We use the data set $\mathrm{TeO}$ Trajectoires et Origines: Enquête sur la diversité des populations de France, collected jointly by INED (Institut National des Études Démographiques) and INSEE (Institut National de la Statistique et des Études Économiques) between 2008 and 2009. This is a unique French survey on ethnicity. It provides rich information on a variety of socio-demographic and socio-economic variables for individuals belonging to different groups of the French population who differ in their origins, as well as information on their family members. It covers French respondents (those whose parents were born French: natives), descendants of immigrants (second-generation immigrants), and immigrants (first-generation immigrants) from a variety of origins. The survey contains additional information about migratory history, and the family and social context during both childhood and adulthood. TeO also provides valuable information on current educational attainment, labor-force participation and earnings. The variables can be broadly organized into three main groups: family and social background (parents' statuses and education, siblings, and 
marital life) ${ }^{8}$ socio-economic outcomes (education, employment, and housing); and migratory history and ethnic belonging (ties to the home country, religion, languages, and ethnic identity).

\subsection{Sample procedure representativeness and non-responses}

The survey includes 21,761 observations on either French-born natives, first-generation immigrants (born abroad and arrived in France at some point in their life) and second-generation immigrants (born in France, but who have at least one foreign-born parent). The immigrant population is overrepresented in the database and weights are used throughout the analysis to produce nationally-representative estimates. The survey is carried out over a two-year period, but individuals are interviewed only once. This is therefore not panel data. Following previous work, we focus our attention on French natives and second-generation immigrants. Including first-generation immigrants is potentially problematic as it does not allow for ceteris paribus comparisons across groups, given that the first generation in general did not go through the French education system. We also drop students, the retired and the self-employed from the data analysis. ${ }^{10}$ Finally we drop individuals with missing values for wages or labor-force status.

\footnotetext{
${ }^{8}$ Note that we have to be careful in interpreting the role of parents' education as the diplomas of non-native parents are not always comparable to those of French native parents. Ideally, one way to control for such differences would be to consider third-generation immigrants. Unfortunately this information was not available in the database.

${ }^{9}$ We acknowledge that the answers given by participants to retrospective questions may not be reliable. This question of the reliability of self-reported schooling is a general issue in the literature. Research generally finds the reliability of self-reported education to be about 90\% (Miller et al. 1995; Ashenfelter and Rouse, 1998; Angrist and Krueger, 1991). For instance Angrist and Krueger (1991) conclude that the reliability of self-reported schooling is 85-90 percent. Griliches (1977) notes that measurement errors in schooling would lead to downward bias in the OLS estimates of the returns to schooling. However, this bias may be partially offset by a possible upward ability bias (Card, 2001).

${ }^{10} \mathrm{We}$ exclude the self-employed as we cannot introduce them in our two-step Heckman procedure to measure wage discrimination. By definition, the self-employed are their "own boss" and have no reason to discriminate against themselves in terms of wages. However we recognize that some individuals may choose self-employment because they are discriminated against by employers. Nevertheless, in our dataset it seems that this is not the case since we find no significant differences in self-employment rates between natives and second-generation immigrants. The self-employed represent $6.24 \%$ of second-generation immigrants and $6.57 \%$ of natives. A similar concern regards discouraged workers who are not considered here. Although we can identify them in the survey,
} 
Our final sample comprises 7939 individuals including 2737 natives and 5202 secondgeneration immigrants. ${ }^{11}$ To investigate the differences across ethnic groups, we separate our final sample of second-generation immigrants into seven subgroups: North African (1422), Sub-Saharan African (481), Turkish (248), Asian (291), Southern European (2147), Northern European (351) and Eastern European (262). ${ }^{12}$ When both parents are immigrants, but from two different areas, we retain the father's origin.

\subsection{Econometric models, methodology and variables of interest}

Our econometric models investigate the determinants of $i$ ) educational attainment (captured by either the highest diploma obtained or schooling failure/success), and ii) employment and iii) hourly wages for both second-generation immigrants and their French native counterparts.

We first present the determinants of educational attainment, and then those of employment. In a third step, after having investigated the ethnic employment gap, we turn to the ethnic wage gap using Mincer wage equations (Mincer, 1974). We first estimate each labor-market outcome in isolation, and then account for selection. Self-selection into work will potentially bias the estimation of wage equations. We control for this via a two-step Heckman procedure (Heckman, 1979). To identify the model we require selection variables that affect the probability of employment but not wages directly. We use standard instruments such as marital

they are not included in our analysis due to the subjective aspect of their status. Furthermore, they only represent $1.52 \%$ of the second-generation and $5.76 \%$ of the native inactive population.

${ }^{11}$ Following the French Republican egalitarian principle, migrants' children are not usually visible in national statistics. This was dealt with in the TeO survey by cross-checking with the 2007 French census and local registers to identify first-generation immigrants' children (in particular from birth certificates).

${ }^{12}$ We define the European sub-groups as follows: Southern Europe comprises Italy (36.46\% of this sub-group), Portugal (32.67\%), Spain (30.19\%) and Greece (0.68\%); Northern Europe Germany (43.02\%), Belgium (32.48\%), United Kingdom (9.40\%), Netherlands (3.42\%), Ireland (3.42\%), Austria (3.13\%), Luxembourg (2.28\%), Denmark (1.71\%) and Sweden (1.14\%); Eastern Europe contains the remainder of the European continent. Secondgeneration immigrants from America, Oceania and Middle East countries are dropped due to small cell sizes. 
status (single man, single woman, working or non-working spouse) and the presence of at least one child (Aeberhardt et al., 2010a) that affect the probability of employment but not earnings. Finally, the fourth step attempts to account for both the selection and endogeneity biases at the same time. We may also have endogeneity bias as the correlation between education and labormarket outcomes (employment, earnings) may differ from the true causal effect of education. For instance, the education variable in the Mincer wage equation may be correlated with the error term, which will lead to an endogeneity problem. A number of authors have pointed out that the earnings differential may also reflect differential ability between groups: individuals with higher wages may also have a comparative advantage in schooling. ${ }^{13}$ Failure to control for this correlation may yield an upward-biased estimate of the effect of education on labor outcomes (Card, 2001). The most widely-used method to estimate the true return to schooling when ability is not observed is instrumental variables (IV) (see Card, 2001 for an extensive review of IV estimates of the return to schooling). ${ }^{14} \mathrm{We}$ control for both selection and endogeneity biases by estimating a bivariate probit model that consists of two simultaneous equations, one for the binary outcome "failure in education" and another for "being employed". Estimation by maximum likelihood yields the Inverse Mills ratio that is then included in the wage equations (Cutillo and Di Pietro, 2005; Jones and Sari, 2015).

\footnotetext{
13 This assumption is known as the signaling or screening hypothesis (Arrow, 1973; Spence, 1974). For instance, suppose that some individuals with low unobserved ability receive lower earnings. If these individuals are more likely to be undereducated, the error in the individual's occupational selection process will be correlated with the error term in the wage equation. There is thus endogeneity bias in the relationship between schooling and earnings, as ability is not taken into account and is therefore included in the error term. Ideally, we should control for individual ability in the estimates. Unfortunately, in most cases we cannot observe this.

${ }^{14}$ IV can suffer from a number of drawbacks. First, IV estimates may be relatively imprecise, making it difficult to establish the size of the ability bias in OLS estimates (see Card, 2001 for a discussion of this point). In the words of Card (2001), "no individual study is likely to be decisive in the debate over the magnitude of ability biases in OLS estimates of the return to schooling" (p. 1157). A second limitation is the restrictive conditions for the choice of the instrument, which should significantly predict education but not be correlated with any other determinants of the dependent variable such as ability for instance (the exclusion restriction).
} 


\section{Results}

We here first evaluate the determinants of the education outcomes of different ethnic groups (Section 3.1), then the ethnic gap in both employment and wages with an attempt to control for potential selection bias (Section 3.2), and last the endogeneity of education in Section 3.3.

\subsection{The determinants of the education outcomes of different ethnic groups.}

We first present some summary statistics and then the education regressions.

\subsubsection{Summary statistics}

Table 1 describes the distribution of the respondent's highest qualification. ${ }^{15}$ Secondgeneration immigrants are more likely to leave school without any qualifications and conversely are less likely to have a university degree. However, schooling performance varies by ethnic origin. Those of Turkish origin have the worst performance, as the fraction with no qualifications is almost twice that of natives; they are also the most likely to have a vocational qualification. On the contrary, immigrants of Asian origin are the least likely not to have qualifications, and outperform immigrants of other origins and natives in terms of having a university qualification. This is consistent with previous work finding that Asians outperform other groups in terms of education (Hirschman and Wong, 1986; Arias, 1986; Lee and Rong, 1988).

[Table 1: about here]

\subsubsection{The Determinants of Educational Attainment}

Table 2 shows the education regression results. It consists of two panels: the left panel refers to the ordered probit estimation of highest qualification, and the right panel (which we will

\footnotetext{
15 These figures should be interpreted with caution since the age structure varies widely between ethnic groups.
} 
discuss later) probit estimation of schooling failure. Within each panel, the first column controls only for demographic variables such as ethnic origin, gender and age, while the second column adds a number of variables related to parental background. We use ordered probits here as education $S$ is an ordered categorical variable as follows: 'No education' $(S=0)$, 'Junior high school' $(S=1)$, 'Vocational studies' $(S=2)$, 'High school' $(S=3)$, 'College' $(S=4)$ and 'University' $(S=5)$. We assume a continuous latent variable $S_{i j}^{*}$ corresponding to the discrete educational attainment of individual $i$ belonging to ethnic group $j$ :

$S_{i j}^{*}=\beta_{0}+\beta_{1} X_{i j}+\beta_{2} \omega_{j}+\gamma_{\mathrm{ij}}$

Given the various categories, we suppose that $S^{*} \leq \mu_{1}$ when $S=0, \mu_{1}<S^{*} \leq \mu_{2}$ when $S=1$, $\mu_{2}<S^{*} \leq \mu_{3}$ when $S=2, \ldots$ and $\mu_{5}<S^{*}$ when $S=5$. The different $\mu$ parameters correspond to a set of thresholds which are estimated jointly with the coefficients, with $\mu_{1}$ being normalized to zero. When $\gamma$ is normally distributed, the corresponding model is a standard ordered probit. The $\omega_{j}$ variables are fixed effects for each ethnic group $j$, with French natives as the omitted category $\left(\omega_{\text {France }}=0\right)$. The error term $\gamma_{\mathrm{ij}}$ is assumed to be normally distributed with parameters $\left(0, \sigma_{u}\right)$. The vector $X_{i j}$ includes the characteristics that are thought to affect education: demographic variables such as gender, age and age-squared, as well as familybackground variables (parents' education and social and health difficulties) and family structure (number of siblings, being the only child, rank among siblings, being in a single-parent family).

Regarding family background, a great deal of work has shown that family income is an important determinant of child school success (Haveman and Wolfe, 1995; Plug and Vijverberg, 2005). ${ }^{16}$ Children from poor families have greater difficulty in pursuing their

\footnotetext{
${ }^{16}$ Recently, economists have shown that the positive relationship between parental income and children's school outcomes may be biased if parental ability is ignored. Plug and Vijverberg (2005) note however that this bias may be overestimated. They appeal to a sample of adopted children, which produces genetically-unbiased estimates, and find that family income still plays a significant role.
} 
education as their parents face credit constraints in paying for their children's education. As our data do not contain information on parental income, we use the occupation of both the father and the mother during the individual's childhood to proxy for the household's financial situation. Beyond these financial aspects, parental education may also be an important determinant of educational attainment in its own right, suggesting an intergenerational correlation in education. This correlation may reflect the genetic transmission of ability to children, or that of informal human capital and preferences. It can reasonably be argued that highly-educated parents will place a greater value on education, and may therefore be more likely to encourage their children to pursue further education. Furthermore, educated parents may also help their children with their schoolwork (e.g. by having books around the house) which may reduce the cost of acquiring education (see for instance Ermisch and Francesconi, 2001). We also include variables related to parental social and health difficulties, such as parents' problems relating to alcohol, violence or money. Last, we account for family structure by including variables related to the number of siblings, being the only child, the rank among siblings, and being in a single-parent family. The role of siblings is ambiguous since welleducated older siblings may produce positive externalities for younger children, whereas having more brothers or sisters might also discourage education through the scarcity of resources (both money and time) in larger families (e.g. Blundell et al., 1997). Furthermore, some research has shown that being in a single-parent family during childhood has a negative effect on education (e.g. Haveman and Wolfe, 1995). Following Belzil and Poinas (2010), we use the highest qualification as the attainment variable (to be estimated via an ordered probit); we also estimate the probability of schooling failure (defined as no qualifications). ${ }^{17}$

\footnotetext{
${ }^{17}$ Following most existing work, we use ordered probit models to estimate the highest grade attained (e.g. Drèze and Kingdon, 2001). A possible limitation of this approach is that the errors are supposed to be homoscedastic, which does not sit comfortably with the possibility of heterogeneous responses that depend on unobservables. Alternatively, we could run a multinomial choice model over the six education levels. However, such models are
} 
[Table 2: about here]

Column (1) shows that women have better education outcomes than do men. This is consistent with previous research on the gender gap in education (see, for instance, Siahaan et al., 2014). Furthermore, our findings indicate that most non-native groups have worse average performance than natives. However, there are considerable differences across ethnic groups. For instance, individuals from Sub-Saharan Africa, Asia and Eastern Europe are not significantly different from French natives. However, those from North Africa, Southern Europe and Turkey have significantly worse education outcomes. These results echo those in existing work. For instance, using the French database "Passage to Retirement of Immigrants", Attias-Donfut and Wolff (2009) find large differences across ethnic groups, with those of Turkish origin performing worse than other ethnic groups. This is found to come from the worse performance of girls. Introducing a Turkish group*gender interaction in our analysis confirms that Turkish girls perform worse (results available upon request). Ethnographic and sociological research on Turkish immigrants in France has explained this gender difference in educational attainment by (i) Turkish families favoring endogamous marriages, which often lead girls to leave school, and (ii) families having ambivalent attitudes towards education, as this is seen as a way of escaping from religious values (see the references in Attias-Donfut and Wolff, 2009, and Domingues Dos Santos and Wolff, 2011).

The findings in column (2) are rather different. After controlling for family background, we no longer find a negative effect of origin on education, with second-generation immigrants being more likely than French natives to have better education outcomes. Most ethnic-origin logit and logit models (available upon request): these produce very similar findings. 
coefficients are now significantly positive (except for Turkish and Eastern European origins, which are no different to French natives). This is consistent with existing work. For instance Brinbaum et al. (2012) also find that ethnic origin no longer predicts schooling failure after controlling for family background. In US data (the 1940 and 1970 Censuses, and the 1994-1996 Current Population Surveys), Card et al. (2000) show that after controlling for a number of variables, second-generation immigrants are on average more educated than the children of comparable US-born parents. Dustmann et al. (2012) also find, in the context of a comparative analysis, that the test-score gap between children born to immigrants and natives falls substantially in most countries when controls for parental characteristics, school and peer quality, and the language spoken at school are introduced.

Our estimation of the determinants of schooling failure, as shown in the right panel of Table 2 (columns (3) and (4)), produces similar results. The only exceptions are that the coefficients on Asian and Southern European origin are no longer significant in column (4), so that children from these ethnic groups perform as well as natives in terms of schooling failure.

Childhood environment thus seems to be a key determinant of education. Parental education and family income are strongly correlated with child education, and having a single parent is associated with worse education outcomes. The negative impact of the number of siblings on education may reveal that families with more siblings have fewer available resources per child. Last, in line with the results of Goux and Maurin (2005), a separate room for homework is positively associated with education outcomes. This can be seen as additional evidence on the importance of educational resources.

These findings then underline the importance of the family and social background. We may then wonder whether the ethnic differences are actually picking up family and social background. We might conjecture that (some) migrant children have less favorable family 
backgrounds than do natives, or that family background matters more for migrant children than for natives. We hence run a number of regressions with interactions between respondents' ethnic origin and family and social background (number of siblings, separate room, family structure and parental education). In these regressions (the results of which are available upon request) none of these interaction variables attract significant and robust (to specification changes) estimated coefficients, suggesting that family background has a similar effect across ethnic groups. The size, structure and resources of the family are then equally important in determining the education outcomes of all ethnic groups. We also check whether secondgeneration immigrants actually do have less favorable family and social backgrounds: Table 3 shows that this is the case, which may explain why ethnic-origin groups have worse educational outcomes than do French natives. North African, Southern European and Turkish parents are less educated than are French parents. Second-generation immigrants with North African, SubSaharan African, Eastern Europe and Turkish parents also have fewer opportunities to do their homework in a separate room. Notably, the number of Eastern-European children with a separate room is almost 30 percentage points lower than their French counterparts. For the three other ethnic groups, the difference is at least 8 percentage points. Sub-Saharan and North African (respectively Asian and Turkish) second-generation immigrants live in families with on average two (0.8) siblings more than French families. Table 3 also shows that Sub-Saharan, Southern and Eastern European origin respondents were brought up less frequently by both parents in a couple. In particular, the percentage of Sub-Saharan individuals reared by both parents in a couple is 14.6 points lower than the figure for French natives. This may be a significant cause of the worse performance of Sub-Saharans, as the probability of schooling failure is $10.3 \%$ higher when the child is brought up by their mother only (see column 4 in Table 2). Last, Northern-European immigrants are not significantly different from French natives, except that their parents were more often in a couple relationship. 
[Table 3: about here]

We provide further evidence on the ethnic education gap, and check whether natives and ethnic groups with comparable characteristics are equally likely to succeed in schooling, via a Blinder-Oaxaca decomposition (Oaxaca, 1973, Blinder, 1974) extended to non-linear regressions on schooling failure/success (see for instance Bauer and Sinning, 2008, and Aeberhardt et al., 2010a, for this decomposition in non-linear models, and Chaudhuri and Roy, 2009 , for the use of this decomposition in the context of schooling). ${ }^{18}$ The main attraction of the method in Aeberhardt et al. (2010a) is that it does not involve the estimation of coefficients for the minority groups, and as there are relatively few observations on immigrant-origin groups, separate regressions may yield inaccurate estimated coefficients. We decompose the gross ethnic difference in schooling failure/success into a component explained by the different characteristics of natives and a particular ethnic group and an unexplained component. The unexplained component is conventionally regarded in the literature as the extent of ethnic discrimination (Oaxaca, 1973, Blinder, 1974). However in the context of education, it is probably better to use the term differential treatment rather than discrimination. A number of factors may appear in the unexplained component, not all of which necessarily reflect discrimination. Among these factors, parents may value education differently by ethnic group (Chiswick, 1988; Dos Santos and Wolff, 2011). The residual gap may also result from lower expectations on the part of parents or teachers toward non-native students, due to anticipated labor-market discrimination against non-natives (Fryer and Levitt, 2004). Finally, the residual gap may indeed reflect discriminatory treatment. There is now a growing literature on discriminatory behavior in education, evaluating the impact of teachers' behavior on the gap

\footnotetext{
${ }^{18}$ For computational reasons we consider here schooling failure/success rather than education attainment.
} 
between natives and ethnic groups. For instance, Dee (2005) provides evidence of taste-based discrimination, noting that the student's odds of being seen as inattentive increases significantly by at least 33 percent when the teacher is not from the same ethnic group. In the same vein, Ouazad (2014) underlines that teachers give better assessments to pupils of their own ethnic group. ${ }^{19}$

The decomposition of the educational gap between natives and second-generation immigrants from group $j$ is given by:

$$
\begin{aligned}
& F_{i j}=1_{F_{i j}^{*}>0} \\
& F_{i j}^{*}=G_{i j} . \alpha+\omega_{j}+u_{i j}
\end{aligned}
$$

where $F_{i j}$ is the schooling-failure probability associated with the latent variable, $F_{i j}^{*}, G_{i j}$ is a vector of the observable determinants of educational attainment, and $\omega_{j}$ is a group $j$ fixed effect. The error term $u_{i j}$ is assumed be normally distributed with parameters $(0,1)$. The probability of schooling failure is:

$$
\operatorname{Prob}\left(F_{i j}=1\right)=\operatorname{Prob}\left(F_{i j}^{*}>0\right)=\operatorname{Prob}\left(u_{i j}>-\left(G_{i j} \cdot \alpha+\omega_{j}\right)\right)=\Phi\left(G_{i j} \cdot \alpha+\omega_{j}\right)
$$

where $\Phi($.$) is the standard normal cumulative distribution function.$

Decomposition methods allow us to split the schooling-failure gap between two groups into a part resulting from differences in observable characteristics such as demographics or family background and a residual part. The decomposition of the schooling-failure gap between natives and second-generation immigrants from group $j$ is given by:

\footnotetext{
${ }^{19}$ These results suggest that the ethnicity of both the teacher and the pupil seems to matter. Unfortunately the TeO survey does not include data on teacher characteristics. However one may reasonably assume that the majority of teachers belong to the native group.
} 


$$
\begin{gathered}
E\left[F_{i f}\right]-E\left[F_{i j}\right]=\underbrace{E_{G_{f}}\left[\mathrm{E}\left(F_{i f} \mid G_{i}\right)\right]-E_{G_{j}}\left[\mathrm{E}\left(F_{i f} \mid G_{i}\right)\right]}_{\text {Explained part }} \\
+\underbrace{E_{G_{j}}\left[\mathrm{E}\left(F_{i f} \mid G_{i}\right)\right]-E_{G_{j}}\left[\mathrm{E}\left(F_{i j} \mid G_{i}\right)\right]}_{\text {Residual gap }}
\end{gathered}
$$

The explained part consists of the difference between French natives' schooling failure and that of second-generation immigrants from group $j$, when both groups have similar returns to characteristics. This part of the educational gap results from differences in characteristics only. On the other hand, the residual gap consists of the part of the schooling gap that is attributed to differences in the return to characteristics.

Following Aeberhardt et al. (2010a,b), we use simple empirical counterparts to carry out this decomposition. ${ }^{20}$

$$
\begin{aligned}
& \frac{1}{N_{f}} \sum_{i \epsilon f} F_{i} \stackrel{a . s}{\rightarrow} E_{G_{f}}\left[\mathrm{E}\left(F_{i f} \mid G_{i}\right)\right] \\
& \frac{1}{N_{j}} \sum_{i \epsilon j} F_{i} \stackrel{\text { a.s }}{\rightarrow} E_{G_{j}}\left[\mathrm{E}\left(F_{i j} \mid G_{i}\right)\right] \\
& \frac{1}{N_{j}} \sum_{i \epsilon j} \Phi\left(G_{i} \cdot \alpha_{f}\right) \stackrel{a . s}{\rightarrow} E_{G_{j}}\left[\mathrm{E}\left(F_{i f} \mid G_{i}\right)\right]
\end{aligned}
$$

Equations (6) and (7) are the simple arithmetical means of schooling failure levels in groups $f$ and $j$. Equation (8) requires the calculation of the coefficients $\alpha_{f}$ in a previous regression on the French native population only, and their application to second-generation immigrants from group $j$. Although this method does not produce an exact decomposition, it has been shown to yield more precise estimates than the usual approach (Aeberhardt et al., 2010a,b).

\footnotetext{
${ }^{20}$ Note that they first use this method to decompose the ethnic employment gap, and that we will also do
} so in Section 3.2.2 below. 
Table 4 shows the results of these educational-gap decompositions between French natives and second-generation immigrants. The procedure is applied both with and without controls for family background in order to assess the impact on schooling failure. We use the same covariates as in regressions (3) and (4) in Table 2, apart for the ethnic-group dummies.

[Table 4: about here]

With no controls for family background, the explained part of the educational gap is negative and the unexplained component is higher than the total educational gap for all ethnic groups (except for Asians and Eastern Europeans). The considerable unexplained component indicates the presence of differential treatment for these ethnic groups as compared to natives. The negative explained component shows that the schooling success of these ethnic groups should be higher due to their better characteristics. For Eastern Europeans, the educational gap is explained by both different characteristics (42\%) and differential treatment (58\%). Northern Europeans succeed more than natives, which does not seem to be explained by their better characteristics but rather by differential treatment in their favor, as shown by the unexplained component that is higher than the total educational gap.

When controlling for family background, the unexplained part of the educational gap falls for all ethnic groups, indicating that the family background is a major determinant of ethnic differences in schooling failure/success. For Eastern Europeans, the residual gap almost disappears, and for North and Sub-Saharan Africans, the predicted gap attributed to characteristics when controlling for family background becomes positive and is larger than the observed gap. This implies that their return to their characteristics is greater than that of natives. For Turkish and Southern Europeans, the residual gap falls but still remains positive, suggesting the persistence of differential treatment for these ethnic groups. Finally, Table 4 indicates that 
Northern Europeans continue to succeed significantly more than natives, after controlling for family background. However this difference remains mostly unexplained.

\subsection{The determinants of labor-market outcomes}

We now go one step further and consider the ethnic gap in labor-market outcomes (employment and wages). After presenting some summary statistics, we investigate the determinants of both employment and wages. We first estimate employment regressions and appeal to the methods popularized by Oaxaca (1973) and Blinder (1973) to decompose the employment gap into a structural part resulting from differences in observable characteristics and a residual part resulting from differences in the return to these same characteristics. We then consider the difference in wages across ethnic groups. Following Aeberhardt et al. (2010a), we correct for potential selection bias, as wages are only observed for the employed. This correction is effected via a two-step Heckman procedure.

\subsubsection{Summary statistics}

Table 5 presents the descriptive statistics regarding employment and hourly wages between ethnic groups in our sample. There are considerable employment and wage differences between second-generation immigrants and French natives, but also between immigrant groups. Secondgeneration immigrants with North-African, Sub-Saharan African or Turkish parents are less likely to be in employment than are natives and receive lower wages on average. ${ }^{21}$ SouthernEuropean immigrant descendants have a lower (but not significantly so) probability of employment but earn on average higher wages. Remarkably, Northern-European immigrant

\footnotetext{
${ }^{21}$ For instance, when considering North Africans, who earn the lowest wages, the average monthly wage differential amounts to 261 Euros.
} 
descendants perform better than French natives in terms of both employment and wages. Last, Table 5 reveals that the children of Asian parents suffer less from lower employment than do some other immigrant-origin groups. ${ }^{22}$

[Tables 5 and 6: about here]

Table 6 provides additional information on the ethnic wage gap, and reveals considerable heterogeneity across ethnic groups. For North and Sub-Saharan Africans, the wage gap increases with both the level of diploma and the ranking in the occupation (from the lowest- to the highest paid professions). For Turkish, Asian and Southern Europeans, the wage gap is significant only for the highest-paid occupations and/or for those who have a high qualification. Northern Europeans receive a wage premium, but this seems to be the case only for employees and workers. As a whole, this Table also shows that wage inequalities mainly arise in highskilled occupations, whereas they are lower for less-skilled jobs. One possible explanation evoked in the literature is the potential impact of minimum wage legislation on the reduction of wage and earnings inequalities (see the empirical analysis of Aeberhardt, Givord and Marbot, 2012).

\subsubsection{The determinants of the ethnic employment gap}

To provide more formal evidence of an ethnic employment gap, we run employment regressions. Let the employment function for individual $i$ in ethnic group $j$ be given by

$$
L_{i j}=1_{L_{i j}^{*}>0}
$$

\footnotetext{
${ }^{22}$ Weighted hourly wage means are compared via a t-test. We use the Rao and Scott (1984) second-order correction of the Pearson $x^{2}$-test to analyze employment differences. We here consider the $10 \%$ significance threshold.
} 


$$
L_{i j}^{*}=H_{i j} \cdot \alpha+\omega_{j}+\varepsilon_{i j}
$$

where $L_{i j}$ is a dummy variable corresponding to employment, $L_{i j}^{*}$ is the associated latent variable, $H_{i j}$ is a vector of the determinants of employment, and $\omega_{j}$ is a group $j$ fixed effect. The error term $\varepsilon_{i j}$ is assumed to follow a normal distribution with parameters $(0,1)$. The probability of employment is:

$$
\operatorname{Prob}\left(L_{i j}=1\right)=\operatorname{Prob}\left(L_{i j}^{*}>0\right)=\operatorname{Prob}\left(\varepsilon_{i j}>-\left(H_{i j} . \alpha+\omega_{j}\right)\right)=\Phi\left(H_{i j} . \alpha+\omega_{j}\right)
$$

where $\Phi($.$) is the standard normal cumulative distribution function.$

Table 7 shows the results from weighted ${ }^{23}$ probit estimations of employment. To emphasize the role of education in ethnic employment gaps, we run estimates with and without the education variables.

[Table 7: about here]

Column (1) of Table 7 shows the estimated coefficients without controls for education. Columns (2) and (3) report similar estimates with a control for schooling failure and educational degree respectively. We include a number of individual characteristics and variables reflecting familial structure. Column (1) shows that North African, Sub-Saharan African and Turkish have a significantly lower probability of employment than do natives. In sharp contrast, NorthernEuropean descendants perform significantly better than do French natives, with an employment probability that is 8 percentage points higher. The insignificant coefficients on the Asian and Southern- or Eastern-European variables reflect no employment difference between these groups and French natives. Controlling for educational qualification in column (3) renders the coefficients on the Turkish variable insignificant. The employment-probability gap for

\footnotetext{
${ }^{23}$ We use the pweight command in Stata10 to include weights in our models.
} 
individuals of North-African origin rather than French origin drops from 7.91 to 5.99 percentage points in column (3). The results in Table 7 thus show that the ethnic employment gap falls significantly when we control for education.

We provide further evidence on the ethnic employment gap via the decomposition method for non-linear estimates previously presented in Section 3.2.1. Given equation (11), the employment gap between natives and second-generation immigrants from group $j$ can be decomposed as:

$$
\begin{gathered}
E\left[L_{i f}\right]-E\left[L_{i j}\right]=\underbrace{E_{H_{f}}\left[\mathrm{E}\left(L_{i f} \mid H_{i}\right)\right]-E_{H_{j}}\left[\mathrm{E}\left(L_{i f} \mid H_{i}\right)\right]}_{\text {Explained part }} \\
+\underbrace{E_{H_{j}}\left[\mathrm{E}\left(L_{i f} \mid H_{i}\right)\right]-E_{H_{j}}\left[\mathrm{E}\left(L_{i j} \mid H_{i}\right)\right]}_{\text {Residual gap }}
\end{gathered}
$$

Implementing empirical counterparts (Aeberhardt et al. 2010a,b) yields

$$
\begin{aligned}
& \frac{1}{N_{f}} \sum_{i \epsilon f} L_{i} \stackrel{a . s}{\rightarrow} E_{H_{f}}\left[\mathrm{E}\left(L_{i f} \mid H i\right)\right] \\
& \frac{1}{N_{j}} \sum_{i \epsilon j} L_{i} \stackrel{\text { a.s }}{\rightarrow} E_{H_{j}}\left[\mathrm{E}\left(L_{i j} \mid H i\right)\right]
\end{aligned}
$$

the simple arithmetic means of employment levels in groups $f(13)$ and $j(14)$, and

$$
\frac{1}{N_{j}} \sum_{i \epsilon j} \Phi\left(H_{i} . \alpha_{f}\right) \stackrel{a . s}{\rightarrow} E_{H_{j}}\left[\mathrm{E}\left(L_{i f} \mid H i\right)\right]
$$

the expected employment probability of second-generation immigrants were their characteristics to be treated in the same way as those of natives on the labor market. 
Table 8 shows the decomposition results. The procedure is applied both with (right panel) and without (left panel) controlling for education to evaluate the effect of the latter on employment access. ${ }^{24}$

[Table 8: about here]

Without controlling for education, there is a considerable residual employment gap for second-generation immigrants from North Africa, Sub-Saharan Africa, Eastern Europe and Turkey. Controlling for education sharply reduces this gap: education is a major determinant of ethnic employment differences. There nonetheless remains a substantial residual gap that may reflect, amongst many other phenomena, the existence of discrimination (Section 4 proposes non-discrimination explanations of this residual gap).

\subsubsection{Wage differentials between ethnic groups correcting for selection bias}

Having considered the ethnic employment gap, we now turn to the ethnic wage counterpart using a Mincer wage equation (Mincer, 1974) as follows:

$\log w_{i j}^{*}=\beta_{0}+\beta_{1} X_{i j}+\beta_{2} \omega_{j}+\beta_{3} S_{i j}+\mu_{i j}$

Here the dependent variable $\log w_{i j}^{*}$ is the $\log$ hourly wage of individual $i$ in ethnic group $j, X_{i j}$ is a vector of the determinants of market wages, $S_{i j}$ corresponds to years of schooling and $\omega_{j}$ are a set of ethnic-group dummies. We can also estimate this Mincer equation replacing the continuous education variable by a dummy for schooling failure or a series of dummy variables corresponding to discrete educational levels (Psacharopoulos and Patrinos, 2004). ${ }^{25}$

\footnotetext{
${ }^{24}$ We use the same covariates as in Table 5, apart for the ethnic group dummies.

25 A number of authors suggest that using dummies may reduce measurement error as the errors in reported schooling are probably mean regressive (see Card, 1999 for a discussion; also Kane et al, 1997, and Psacharopoulos and Patrinos, 2004).
} 
$\log w_{i j}=\alpha+\beta X_{i j}+b_{1} S_{i j 1}+b_{2} S_{i j 2}+b_{3} S_{i j 3}+b_{4} S_{i j 4}+b_{5} S_{i j 5}+\delta_{j}+\mu_{i j}$

The Mincer wage equations can be estimated using OLS. However the estimates may suffer from potential selection bias, as wages are only observed for those in employment, who may have different (un)observable characteristics to the unemployed. Following Aeberhardt et al. (2010a,b), we control for selection using the Heckman two-step procedure. ${ }^{26}$ Let the employment function for individual $i$ in ethnic group $j$ be

$$
L_{i j}^{*}=H_{i j} \cdot \alpha+\omega_{j}+\varepsilon_{i j}
$$

where $H_{i j}$ includes some of the characteristics in $X_{i j}$ plus a set of instruments for being employed. For the model to be identified, we require selection variables that affect the probability of employment, but not wages directly. We use standard instruments (Aeberhardt et al., 2010a) such as marital status (single man, single woman, working or non-working spouse) and the presence of at least one child.

Any correlation $\rho$ between the error terms of our two equations introduces potential bias. We estimate the wage equation for the employed, which is expressed as

$$
\begin{aligned}
& \log w_{i j} \mid L_{i j}^{*}>0=X_{i j} \cdot \beta+\omega_{j}+\rho \cdot \sigma_{u} \cdot \lambda_{i j} \\
& \lambda_{i j}=\frac{\phi\left(H_{i j} \cdot \alpha+\omega_{j}\right)}{\Phi\left(H_{i j} \cdot \alpha+\omega_{j}\right)}
\end{aligned}
$$

where $\phi($.$) is the standard normal density distribution function, \Phi($.$) the standard cumulative$ normal distribution and $\lambda_{i j}$ the inverse Mills ratio. We can thus test for selection bias $(\rho \neq 0)$ and correct for it.

\footnotetext{
${ }^{26}$ We appeal to maximum-likelihood estimators, which are known to be more efficient than the original two-step procedure (Puhani, 2000).
} 
Table 9 reports wage-equation estimates using two different econometric methods: the right panel (models 1-4) shows simple weighted OLS regression results, while the left panel (models 5-6) controls for selection bias. In column (1) age has a positive (but non-linear, as shown by the negative age-squared coefficient) effect on wages. The negative and highly significant coefficients on "North-African" and "Sub-Saharan African" origin in column (1) indicate a significant ethnic wage gap. Consistent with previous work, we also see a significant gender gap in wages. ${ }^{27}$

[Table 9: about here]

Unsurprisingly, models (2) and (3) show that education is an important determinant of wages. Controlling for educational qualification (column 3), the ethnic wage gap persists but is less significant and smaller in size. Turkish origin attracts a positive coefficient in column (3) when controlling for education, and Asian and European second-generation immigrants have similar wages to French natives.

Columns (4)-(6) are analogous to columns (1)-(3) but control for selection bias. ${ }^{28}$ The "Sub-Saharan African" variable is no longer significant here, while the "North-African" origin variable is less significant in column (4) than in column (1) (and after controlling for education in columns (5) and (6) becomes insignificant). Finally, Turkish second-generation immigrants benefit from a wage premium relative to natives after controlling for education.

\footnotetext{
${ }^{27}$ Controlling for occupation allows us to capture any occupational particularity; however, it may lead to an underestimate of discrimination if access to certain occupations is itself discriminatory.

${ }^{28}$ That the inverse Mills ratio is insignificant in some estimates does not necessarily imply that there is no selection bias within each ethnic group. This is due to the selection bias being different in both extent and nature between natives and second-generation immigrants. When we run regressions for each subgroup, we obtain a Mills ratio that is significantly positive for natives and significantly negative for second-generation immigrants, which is why we observe an insignificant Mills ratio in the whole-sample estimation.
} 
Overall, these results show that, with the exception of those of Turkish origin, ethnic wage gaps completely disappear after controlling for both selection bias and education. These findings add to the previous results of Aeberhardt et al. (2010a,b) and shed light on the heterogeneity between different immigrant types.

We further investigate the ethnic wage gap via the decomposition method in Aeberhardt et al. (2010a). ${ }^{29}$ This counterfactual approach, inspired by standard decomposition techniques (Oaxaca, 1973; Blinder, 1973), only requires the estimation of wages for French natives. We use two simple counterfactuals to decompose the wage gap between French natives $f$ and the second-generation group $j$ :

$$
\begin{aligned}
& w_{j}^{*}=\sum_{i \in j}\left(\frac{\Phi\left(H_{i} \cdot \widehat{\alpha}_{f}\right)}{\sum_{i} \Phi\left(H_{i} \cdot \widehat{\alpha}_{f}\right)}\right)\left(X_{i} \cdot \hat{\beta}_{f}+\hat{\rho}_{f} \cdot \hat{\sigma}_{f} \cdot \frac{\phi\left(H_{i} \cdot \widehat{\alpha}_{f}\right)}{\Phi\left(H_{i} \cdot \widehat{\alpha}_{f}\right)}\right) \\
& w_{j}^{* *}=\sum_{i \in j}\left(\frac{L_{i}}{\sum_{i} L_{i}}\right)\left(X_{i} \cdot \hat{\beta}_{f}+\hat{\rho}_{f} \cdot \hat{\sigma}_{f} \cdot \frac{\phi\left(H_{i} \cdot \widehat{\alpha}_{f}\right)}{\Phi\left(H_{i} \cdot \widehat{\alpha}_{f}\right)}\right)
\end{aligned}
$$

The first counterfactual $w_{j}^{*}$ corresponds to the average wage that an individual from group $j$ could earn were he to be selected and paid in the same way as those in the French native group. The second counterfactual $w_{j}^{* *}$ represents the average wage that an employed individual from group $j$ could expect were he to be paid in the same way as French natives.

\footnotetext{
${ }^{29}$ Despite the advantages of the Blinder-Oaxaca approach, this method may have some limitations. We thank an anonymous referee for this helpful remark. A first is that the wage gap is estimated around the mean value of the total population and thus provides no information about the distribution of earnings differences (e.g. Jenkins, 1994). A second is that the relationship between characteristics and earnings is not necessarily linear (e.g. Heckman, Lochner and Todd, 2003). Another is that it may under-estimate labor-market discrimination by not taking into account feedback effects from labor-market discrimination on individual characteristics, (Oaxaca 1973, p.708): some individual characteristics such as human capital may themselves reflect discrimination (Oaxaca, 1973, Grimshaw et al. 2002). Individuals may also invest less in human capital if they anticipate lower returns, which themselves show current discrimination (Grimshaw et al. 2002). Discrimination may also be blurred by omitted-variable bias, making it difficult to identify accurately. Finally, the Blinder-Oaxaca approach does not restrict the comparison to comparable individuals, which likely upwardly biases the unexplained pay difference estimate (e.g. Barsky et. al. 2002).
} 
The decomposition of the wage gap between French natives $f$ and the second-generation group $j$ is then written as follows

$$
\bar{w}_{f}-\bar{w}_{j}=\underbrace{\bar{w}_{f}-w_{j}^{*}}_{\text {Explained part }}+\underbrace{w_{j}^{*}-w_{j}^{* *}}_{\text {Selectivity }}+\underbrace{w_{j}^{* *}-\bar{w}_{j}}_{\text {Residual gap }}
$$

Table 10 presents the ethnic wage gap decomposition results. The wage gap is expressed here as the difference in the log hourly wage between French natives and second-generation immigrants. As noted above, we decompose these gaps into three components. The first corresponds to the proportion explained by the observed characteristics of the two groups, the second the differences between the two groups in terms of selection, and the third the residual gap, i.e. the proportion of the gap which is explained neither by observed characteristics nor by selection. The table shows each component as a percentage of the initial raw gap. Again, controlling for education reduces the residual part and increases the explained part of the wage gap. Overall, these and our previous findings suggest that education differences between ethnic groups are particularly important in explaining employment and wage gaps.

[Table 10: about here]

\subsection{Controlling for the endogeneity bias}

In the previous section we considered Mincer equations controlling for the selection bias. However, as mentioned above, estimates of determinants of labor outcomes (employment and earnings) may equally suffer from endogeneity bias. We account for both biases as in Cutillo and Di Pietro (2005) and Jones and Sari (2015), and estimate in a first step a bivariate probit model of the binary outcomes "schooling failure" and "being employed". For computational reasons, we focus here on schooling failure instead of educational attainment (otherwise we would need a linear probability model for educational attainment, which suffers from a number 
of limitations: see Horrace and Oaxaca, 2006, and Black et al. 2005). Our bivariate probit model is as follows:

$\left\{\begin{array}{l}S_{i j}^{*}=\gamma Z^{\prime}{ }_{i j S}+\omega_{j}+\zeta_{i j} \\ L_{i j}^{*}=\alpha Z^{\prime}{ }_{i j L}+\omega_{j}+\varepsilon_{i j}\end{array}\right.$

where $S_{i j}^{*}$ and $L_{i j}^{*}$ are the latent variables associated with the probability of schooling success/failure and employment, respectively, $Z_{i j L}$ a set of individual characteristics influencing the probability of being employed, $Z_{i j s}$ includes some of the characteristics included in $Z_{i j L}$ plus a set of instruments for educational success, and $\omega_{j}$ is a group-j fixed effect. In addition, we require some instrumental variables that influence employment but not wages, so that these variables appear in $Z_{i j L}$ but not $X_{i j}$ in equation (16). As mentioned in the previous sub-section, these variables include marital status as well as spouse's occupation. Finally, the identification of the model requires that $Z_{i j S}$ include at least one instrumental variable that explains the probability of educational success but neither the probability of being employed nor earnings. In other words these instrumental variables should not appear in either $Z_{i j L}$ or $X_{i j}$, i.e. the vector of characteristics that are thought to affect wages. Our potential candidates as instrumental variables in $Z_{i j s}$ are the presence of a separate room for the child, the number of siblings (see Angrist and Krueger, 1991), and family size and/or birth order (Black et al. 2005). ${ }^{30}$ The error terms $\zeta_{i j}$ and $\varepsilon_{i j}$ are assumed to be normally distributed. Maximum likelihood estimation allows to calculate the Inverse Mills ratios that will be included in the second-step wage equations, which are as follows:

\footnotetext{
${ }^{30}$ Greater family size may negatively affect child outcomes through resource dilution (Becker, 1960), although this can be partly offset by larger families helping to stabilize marriages and thus reduce the probability of education failure. The empirical evidence leans toward a negative correlation between family size and education. This is the case in Black et al. (2005) in data on the entire population of Norway. However, this correlation turns insignificant when the authors include indicators for birth order and use twin births as an instrument. The authors also find a negative significant birth-order effect on child education.
} 
$\log w_{i j} \mid L_{i j}^{*}>0=X_{i j 1} \cdot \beta_{1}+\omega_{j}+a_{1} \cdot \lambda_{i j s}+a_{2} \cdot \lambda_{i j L}$

where $\lambda_{i j S}$ and $\lambda_{i j L}$ are the Inverse Mills ratios and the $a$ 's their coefficients. The results appear in Table 11. Columns (1) and (2) show the findings for the determinants of schooling failure and employment, respectively, and column (3) the estimate for the determinants of wages after controlling for both selection and endogeneity bias.

Overall, these results in Table 11 confirm our previous findings. Column (1) of Table 11 presents very similar findings to those in column (4) of Table 2 on the determinants of schooling failure. Similarly, column (2) of Table 11 provides similar findings to those in column (3) of Table 7. Finally, column (3) of Table 11 confirms our previous findings, i.e. that none of the origin variables is significant except the positive and significant Turkish coefficient, indicating that Turkish second-generation immigrants benefit from a wage premium relative to natives. $^{31}$

[Table 11: about here]

\section{Discussion and conclusions}

Using data from the French Trajectoires et Origines survey, we have considered the determinants of the ethnic gaps in education and labor-market outcomes between natives and second-generation immigrants. To our knowledge, this is the only dataset providing accurate information on the life-course of second-generation immigrants in France. We have three main findings.

\footnotetext{
${ }^{31} \mathrm{We}$ also ran separate wage estimates by success/failure at school (available upon request). These indicate a wage premium relative to natives only for Turkish second-generation immigrants who succeeded at school.
} 
First, childhood environment is a key determinant of education. Controlling for family background knocks out the negative effect of ethnic origin on education. This latter even turns positive, suggesting that the educational achievement of the children of immigrants results from their parents' placing great value on education (see Siahaan et al. 2014). This result also echoes the explanations found in the sociology of education literature that immigrants believe more than natives that education is a vehicle for social mobility (see for instance, Kao and Tienda, 1995). As such, they invest more in education. Another explanation is that second-generation immigrants anticipate that they will be later discriminated against on the job market and hence invest more in education to counteract this potential future discrimination. This sharply contrasts with the idea that second-generation immigrants under-invest in education because they suffer from discrimination at school or because they anticipate lower returns on the labor market (see for instance the theoretical setups in Lundberg and Startz, 1983, and Keane and Wolpin, 2000). ${ }^{32}$

We also find that education plays a prominent role in explaining both the employment and wage gaps between French natives and second-generation immigrants. Although secondgeneration immigrants are less likely to be employed and receive lower wages than do natives, we show nonetheless that education plays a major role in explaining both the employment and wage gaps. Controlling for education sharply reduces the ethnic employment gap. The ethnic wage gaps disappear after controlling for education and selection and endogeneity biases, with a wage premium for Turkish second-generation immigrants relative to natives.

\footnotetext{
${ }^{32}$ In these models, negative prior beliefs about members of a particular group may become self-fulfilling in equilibrium (Lundberg and Startz, 1983). This may occur for example if individuals of a particular group underinvest in human capital due to anticipated discriminatory treatment and therefore a lower return to education.
} 
A third finding is the existence of considerable heterogeneity across ethnic groups in terms of educational attainment, but also employment and wages. These differences seem to be mainly driven by family background.

Overall, childhood environment is a key determinant of life-course success, as it affects education which itself affects labor-force outcomes. Our result on the impact of family background on educational attainment, which in turn is key for labor-market integration, is in line with the findings of existing work emphasizing the role of "premarket" factors in adult earnings outcomes (see Todd and Wolpin, 2007).

Our findings suggest that targeting the education gap via family-oriented policies may reduce ethnic gaps in the labor market. ${ }^{33}$ Education policies such as early-childhood education, kindergarten, homework assistance, and so on, which act as a counterweight to certain aspects of family background, may help to attenuate education gaps. Nevertheless the existence of a residual ethnic employment gap after controlling for educational attainment suggests that other unobservable non-education factors such as hiring discrimination play a non-negligible role in ethnic labor-market outcomes. Future research will help to further determine the exact effect of discrimination in determining French labor-market outcomes.

\section{References}

Aeberhardt, R., Fougère, D., Pouget, J., \& Rathelot, R. (2010a). Wages and employment of French workers with African origin. Journal of Population Economics, 23(3), 881-905.

Aeberhardt, R., Fougère, D., Pouget, J., \& Rathelot, R. (2010b). L'emploi et les salaires des enfants d'immigrés. Economie et statistique, 433(1), 31-46.

Aeberhardt, R., Givord, P., \& Marbot, C. (2012). Spillover effect of the minimum wage in France : An Unconditional Quantile Regression Approach. Direction des Etudes et Synthèses Economiques Working Paper, G2012/07.

\footnotetext{
${ }^{33}$ This interpretation of the residual employment gap requires caution, as the latter may reflect not only discrimination, but also unobserved differences in ability, attitudes or preferences. One limitation of our work here is that we cannot disentangle these explanations. This is a general difficulty in most survey data without information on discrimination at the hiring stage. Recent developments have emphasized the value of field and laboratory experiments in circumventing this difficulty (See Riach and Rich, 2002, for an exhaustive survey of field experiments).
} 
Aeberhardt, R., \& Pouget, J. (2010). National origin differences in wages and hierarchical positions. Annals of Economics and Statistics, 99/100, 117-139.

Algan, Y., Dustmann, C., Glitz, A., \& Manning, A. (2010). The Economic Situation of First and Second-Generation Immigrants in France, Germany and the United Kingdom. Economic Journal, 120(542), 4-30.

Algan, Y., Landais, C., \& Senik, C. (2012). Cultural integration in France, in Cultural Integration of Immigrants in Europe, Algan, Y. Bisin, A., Manning, A. and Verdier, T. (Eds.), Oxford University Press.

Altonji, J. G., \& Blank, R. M. (1999). Race and gender in the labor market. Handbook of Labor Economics, 3, 3143-3259.

Angrist, J., \& Krueger A. (1991). Does compulsory school attendance affect schooling and earnings? Quarterly Journal of Economics, 106(4), 979-1014.

Arias B., (1986). The context of education for Hispanic students: An Overview. American Journal of Education, 95(1), 26-57.

Arrow, K.J. (1973). The Theory of Discrimination. In: Ashenfelter, O., Rees, A. (Eds.), Discrimination in Labor Markets. Princeton University Press, 3-33.

Ashenfelter, O., \& Rouse C. (1998) Income, schooling, and ability: Evidence from a new sample of identical twins. Quarterly Journal of Economics, 113(1), 253-284.

Attias-Donfut, C. \& Wolff, F. C. (2009). Le destin des enfants d'immigrés. Editions Stock.

Baker, M., \& Benjamin, D. (1994). The performance of Immigrants in the Canadian Labor Market, Journal of Labor Economics, 12(3), 369-405.

Barsky, R., Bound, J., Charles, K. K. \& Lupton, J. P. (2002). Accounting for the black-white wealth gap: A nonparametric approach. Journal of the American Statistical Association, 97(459), 663-673.

Bauer, T. K., \& Sinning, M. (2008). An extension of the Blinder-Oaxaca decomposition to nonlinear models. AStA Advances in Statistical Analysis, 92(2), 197-206.

Becker, G. S. (1957). The Economics of Discrimination. University of Chicago Press.

Becker, G. S. (1960). An Economic Analysis of Fertility. Demographic and Economic Change in Developed Countries. Princeton: Princeton University Press.

Beenstock, M. B., Chiswick, R., \& Paltiel, A. (2005), Endogenous Assimilaton and Immigration Adjustment in Longitudinal Data, IZA Discussion Paper 1840.

Belzil, C., \& Poinas, F. (2010). Education and early career outcomes of second-generation immigrants in France. Labour Economics, 17(1), 101-110.

Bevelander, P., \& Nielsen, H. S. (2001). Declining employment success of immigrant males in Sweeden: Observed or unobserved characteristics? Journal of Population Economics, 14(3), 455-472.

Bisin, A., \& Verdier, T. (2011) The economics of cultural transmission and socialization. In: Benhabib, J., Bisin, A., \& Jackson, M. (Eds), Handbook of Social Economics, Vol 1A. Elsevier, North-Holland, 339-416

Black, S., Devereux, P., \& Salvanes, K. (2005). The more the merrier? The effect of family size and bith order on children's education. Quarterly Journal of Economics, 120(2), 669-700. 
Blau, F. D., \& Kahn, L. M. (2005) Gender Assimilation among Mexican Americans. NBER Working Paper 11512.

Bleakley, H., \& Chin, A. (2010). Age at arrival, English proficiency and social assimilation among U.S. immigrants. Amercian Economic Journal: Applied Economics, 2(1), 165-192.

Blinder, A. S. (1973). Wage discrimination: reduced form and structural estimates. Journal of Human Resources, 8(4), 436-455.

Blundell, R., Dearden, L., Goodman, A., \& Reed, H. (1997). Higher education, employment and earnings in Britain. London: Institute for Fiscal Studies.

Borjas, G. J. (1993). The intergenerational mobility of Immigrants. Journal of Labor Economics, 11(1), 113-135.

Borjas, G. (1995). Assimilation, changes in cohort quality revisited: what happened to immigrant earnings in the 1980s? Journal of Labor Economics, 13(2), 201-245.

Borjas, G. J. (1999). The economic analysis of immigration. Handbook of Labor Economics, 3, 1697-1760.

Borjas G., (2006). Making it in America : Social mobility in the immigrant population. NBER Working Paper 12088.

Brinbaum, Y., Moguérou, L., \& Primon, J. L. (2012). Les enfants d'immigrés ont des parcours scolaires différenciés selon leur origine migratoire. Insee Références Immigrés et descendants d'immigrés en France, 43-49.

Card D. (2001). Estimating the return to schooling: Progress on some persistent econometric problems. Econometrica 69(5), 1127-1160.

Card, D. (2005). Is New Immigration Really so Bad? Economic Journal, 115(507), 300-323.

Card, D., DiNardo, J., \& Estes, E. (2000). The More Things Change. Immigrants and the Children of Immigrants in the 1940s, the 1970s, and the 1990s. In Borjas G. (Eds), Issues in the Economics of Immigration, 227-270, Chicago: University of Chicago Press.

Carliner, G. (1980). Wages earnings and hours of first, second and third generation American Males. Economic Inquiry, 18(1), 87-102.

Casey, T., \& Dustmann, C. (2010). Immigrants' identity, economic outcomes and the transmission of identity across generations. Economic Journal, 120(542), 31-51.

Casey, T., \& Dustmann, C. (2008). Intergenerational transmission of language capital and economic outcomes. Journal of Human Resources, 43(3), 299-324.

Chaudhuri K., \& Roy S. (2009). Gender gap in educational attainment: Evidence from rural India, Education Economics, 17(2), 215-238.

Chiswick, B. R. (1977). Sons of immigrants: Are they at an earnings disadvantage? American Economic Review Papers and Proceedings, 67(1), 376-380.

Chiswick, B. R. (1988). Differences in education and earnings across racial and ethnic groups: tastes, discrimination and investment in child quality Quarterly Journal of Economics, 103(3), 571-597.

Chiswick, B. R., \& DebBurman, N. (2004). Educational attainment: Analysis by immigrant generations. Economics of Education Review, 23(4), 361-379. 
Coate S., Loury G., 1993. Will affirmative-action policies eliminate negative stereotypes?, American Economic Review, 83(5), 1220-1240.

Constant, A., \& Massey, D. S. (2003). Self-selection, earnings and out-migration: A longitudinal study of immigrants to Germany. Journal of Population Economics, 16(4), 631653.

Constant, A., Gataullina, L., Zimmermann, K., \& Zimmermann, L. (2006) Clash of cultures: Muslims and Christians in the ethnosizing process. IZA Discussion Paper 2350

Cutillo, A., \& Di Pietro, G. (2005). The effects of overeducation on wages in Italy: A bivariate selectivity approach. International Journal of Manpower, 27(2), 143-168.

Dee, T. S. (2005). A teacher like me: Does race, ethnicity, or gender matter? American Economic Review, 95(2), 158-165.

Domingues Dos Santos, M., \& Wolff, F. C. (2011). Human capital background and the educational attainment of second-generation immigrants in France. Economics of Education Review, 30(5), 1085-1096.

Drèze, J., \& Kingdon, G. G. (2001). School participation in rural India. Review of Development Economics, 5(1), 1-24.

Duleep, H. O., \& Regets, M .C. (1996). Earnings convergence: Does it matter where immigrants come from or why? Canadian Journal of Population Economics, 29(1), S130-S134

Duleep H. O., \& Dowhan, M. C. (2002). Insights from longitudinal data on earnings of US foreign-born men. Demography, 39(3), 485-506.

Dustmann, C. (1993). Earnings adjustment of temporary migrants. Journal of Population Economics, 6(2), 153-168.

Dustmann, C. \& Glitz A. (2011). Migration and education. Handbook of the Economics of Education, 4, 327-439.

Dustmann, C., Glitz, A., \& Frattini, T. (2008). The labour market impact of immigration. Oxford Review of Economic Policy, 24(3), 477-494.

Dustmann, C. (2008). Return migration, investment in children, and intergenerational mobility: Comparing sons of foreign- and native-born fathers. Journal of Human Resources, 43(2), 299324.

Dustmann, C., Machin, S., \& Schönberg, U. (2010). Ethnicity and educational achievement in compulsory schooling. Economic Journal, 120(46), F272-F297.

Dustmann, C., \& Theodoropoulos, N. (2010). Ethnic minority immigrants and their children in Britain. Oxford Economic Papers, 62(2), 209-233.

Dustmann, C., Frattini, T., \& Lanzara, G. (2012). Educational achievement of secondgeneration immigrants: an international comparison. Economic Policy, 27(69), 143-185.

Ermisch, J., \& Francesconi, M. (2001). Family matters: Impacts of family background on educational attainments. Economica, 68(270), 137-156.

Friedberg R., (1992). The Labor Market Assimilation of Immigrants in the United States: The Role of Age at Arrival. Brown University.

Friedberg, R. (2000). You can't take it with you? Immigrant assimilation and the portability of human capital: Evidence from Israel. Journal of Labor Economics, 18(2), 221-251. 
Fryer R., \& S. D. Levitt (2004). Understanding the Black-White test score gap in the first two years of school. Review of Economics and Statistics, 86(2), 447-464.

Fryer, R. and P. Torelli (2010). An empirical analysis of acting white. Journal of Public Economics, 94(5-6), 380-396.

Gang, I. N., \& Zimmermann, K. F. (2000). Is child like parent? Educational attainment and ethnic origin. Journal of Human Resources, 35(3), 550-569.

Goux, D., \& Maurin, E. (2005). The effect of overcrowded housing on children's performance at school. Journal of Public Economics, 89(5), 797-819.

Griliches, Z. (1977). Estimating the returns to schooling: some econometric problems. Econometrica, 45(1), 1-22

Grimshaw, D. \& Rubery, J. (2002). The adjusted gender pay gap: A critical appraisal of standard decomposition techniques" Manchester School of Management, UMIST

Haveman, R., \& Wolfe, B. (1995). The determinants of children's attainments: A review of methods and findings. Journal of Economic Literature, 33(4), 1829-1878.

Heckman, J. (1979). Sample selection bias as a specification error. Econometrica, 47(1), 153161.

Heckman, J. J., Lochner, L. J., \& Todd, P. E. (2003). Fifty years of Mincer earnings regressions. NBER Working Paper 9732.

Hirschman C., \& Wong, M. G. (1986). The extraordinary educational attainment of Asian Americans: A search for historical evidence and explanations. Social Forces, 65(1), 1-27.

Horrace, W. C., \& Oaxaca, R. L. (2006). Results on the bias and inconsistency of ordinary least squares for the linear probability model. Economics Letters, 90(3), 321-327.

$\mathrm{Hu}, \mathrm{W}$. Y. (2000). Immigrant earnings: estimates from longitudinal data. American Economic Review, 90(2), 368-372.

Jenkins, S.P. (1994). Earnings discrimination measurement: a distributional approach. Journal of Econometrics, 61(1), 81-102.

Jones, E., \& Sari, F. (2015). L'adresse contribue-t-elle à expliquer les écarts de salaires ? Le cas de jeunes sortant du système scolaire. Working paper halshs 01112663.

Kao, G., \& Tienda, M. (1995). Optimism and achievement: the educational performance of immigrant youth. Social Science Quarterly, 76(1), 1-19.

Keane, M. P., \& Wolpin, K. I. (2000). Eliminating race differences in school attainment and labor market success. Journal of Labor Economics, 18(4), 614-652.

Lee E. S., \& Rong, X.L. (1988). The educational and economic achievement of Asian Americans. Elementary School Journal, 88(5), 545-560.

Lombardo, P., \& Pujol, J., (2011). Le niveau de vie des descendants d'immigrés. DossierNiveau de vie et pauvreté des immigrés en 2007, 37-44.

Longva, P., \& Raaum, O. (2003). Earnings assimilation of immigrants in Norway. A reappraisal. Journal of Population Economics, 16(1), 177-193.

Losen D., Orfield G. (2002). Minority Issues in Special Education, The civil rights project at Harvard University and Harvard Education Press, Cambridge. 
Lundberg, S. J., \& Startz, R. (1983). Private discrimination and social intervention in competitive labor markets. American Economic Review, 73(3), 340-347.

Meurs, D., \& Pailhé, A. (2010). Position sur le marché du travail des descendants directs d'immigrés en France : les femmes doublement désavantagées ? Economie et statistiques, 431(1), 129-151.

Meurs, D., Pailhé, A., \& Simon, P. (2006). The persistence of international inequalities linked to immigration: Labour market outcomes for immigrants and their descendants in France. Population, 61(5), 645-682.

Miller, P., Mulvey, Ch., \& Martin, N. (1995). What do twin studies reveal about the economic returns to education? A comparison of Australian and U.S. findings. American Economic Review, 85(3), 586-599.

Mincer, J. (1974) Schooling, Experience and Earnings, Columbia University Press: New York.

Mitrut A. and F.-C. Wolff (2014). Investing in children's education: are Muslim immigrants different? Journal of Population Economics, 27(4), pp 999-1022.

Oaxaca, R. (1973). Male-female wage differentials in urban labor markets. International Economic Review, 14(3), 693-709.

Ouazad, A. (2014). Assessed by a teacher like me: Race and teacher assessments. Education, 9(3), 334-372.

Plug, E., \& Vijverberg, W. (2005). Does family income matter for schooling outcomes? Using adoptees as a natural experiment. Economic Journal, 115(506), 879-906.

Portes, A., \& Rumbaut, R. G. (1990). Immigrant America. University of California Press

Psacharopoulos, G., \& Patrinos, H.A., (2004). Returns to investment in education : A further update. Education Economics, 12(2), 111-134.

Puhani, P. (2000). The Heckman correction for sample selection and its critique. Journal of Economic Surveys, 14(1), 53-68.

Rao, J. N., \& Scott, A. J. (1984). On chi-squared tests for multiway contingency tables with cell proportions estimated from survey data. The Annals of Statistics, 12(1), 46-60.

Riach, P. A., \& Rich, J. (2002). Field experiments of discrimination in the market place. Economic Journal, 112(483), 480-518.

Rong, X. L., \& Grant, L. (1992). Ethnicity, generation and school attainment of Asians, Hispanics and Non Hispanic whites. The Sociological Quarterly, i(4), 625-636.

Siahaan, F., Lee, D. Y., \& Kalist, D. E. (2014). Educational attainment of children of immigrants: Evidence from the national longitudinal survey of youth. Economics of Education Review, 38, 1-8.

Spence, M. (1974). Job Market Signaling. Quarterly Journal of Economics, 87(3), 355-374.

Trajectoires et origines (TeO) - version complète - 2008 - (2008) [Fichier électronique], INED et INSEE [producteur], Centre Maurice Halbwachs (CMH) [diffuseur]

Todd, P. E., \& Wolpin, K. I. (2007). The production of cognitive achievement in children: Home, school, and racial test score gaps. Journal of Human Capital, 1(1), 91-136. 
Van Ours, J. C., \& Veenman, J. (2003). The educational attainment of second-generation immigrants in The Netherland. Journal of Population Economics, 16(4), 739-753 